\title{
ARBUSCULAR MYCORRHIZAL FUNGAL COMMUNITIES AND SOIL AGGREGATION AS AFFECTED BY CULTIVATION OF VARIOUS CROPS DURING THE SUGARCANE FALLOW PERIOD ${ }^{(1)}$
}

\author{
Priscila Viviane Truber ${ }^{(2)} \&$ Carolina Fernandes ${ }^{(3)}$
}

\begin{abstract}
SUMMARY
Management systems involving crop rotation, ground cover species and reduced soil tillage can improve the soil physical and biological properties and reduce degradation. The primary purpose of this study was to assess the effect of various crops grown during the sugarcane fallow period on the production of glomalin and arbuscular mycorrhizal fungi in two Latosols, as well as their influence on soil aggregation. The experiment was conducted on an eutroferric Red Latosol with high-clay texture $\left(680 \mathrm{~g}^{\left.\text {clay } \mathrm{kg}^{-1}\right)}\right.$ and an acric Red Latosol with clayey texture (440 $\mathrm{g} \mathrm{kg}^{-1}$ clay) in Jaboticabal (São Paulo State, Brazil). A randomized block design involving five blocks and four crops [soybean (S), soybean/fallow/soybean (SFS), soybean/millet/soybean (SMS) and soybean/sunn hemp/soybean (SHS)] was used to this end. Soil samples for analysis were collected in June 2011. No significant differences in total glomalin production were detected between the soils after the different crops. However, total external mycelium length was greater in the soils under SMS and SHS. Also, there were differences in easily extractable glomalin, total glomalin and aggregate stability, which were all greater in the eutroferric Red Latosol than in the acric Red Latosol. None of the cover crops planted in the fallow period of sugarcane improved aggregate stability in either Latosol.
\end{abstract}

Index terms: glomalin, hyphae, eutroferric Red Latosol, acric Red Latosol.

(1) Part of the first author's master's thesis, funded by Fapesp (Process 2011/06491-0), Fundunesp (Process 314/11-DFP) and PROPe-UNESP (Edital 05/11). Received for publication on January 31, 2013 and approved on December 5, 2013.

(2) Master in Agronomy (Soil Science), FCAV/UNESP, Department of Soil Science. Via de Acesso Prof. Paulo Donato Catellane, s/n. CEP 14884-900 Jaboticabal (SP), Brazil. CNPq grant holder. E-mail: priscilaviviane@gmail.com

(3) Assistant Professor, Department of Soil Science, UNESP, Campus de Jaboticabal. E-mail: carol@fcav.unesp.br 


\title{
RESUMO: COMUNIDADE DE FUNGOS MICORRÍZICOS ARBUSCULARES E AGREGAÇÃO DO SOLO APÓS O CULTIVO DE DIFERENTES CULTURAS NO PERÍODO DE REFORMA DO CANAVIAL
}

\begin{abstract}
Os sistemas de manejo que adotam menor revolvimento do solo, rotação de culturas e utilização de plantas de cobertura podem levar a melhorias dos seus atributos biológicos e físicos, com redução da degradação do solo. $O$ objetivo deste estudo foi avaliar o cultivo de diferentes culturas, durante o período de reforma do canavial, na produção de glomalina e na de propágulos de fungos micorrízicos arbusculares, em dois Latossolos, e a influência desses nos processos de agregação do solo. O experimento foi conduzido no município de Jaboticabal, $S P$, em um Latossolo Vermelho eutroférrico (LVef) textura muito argilosa (680 $\mathrm{g} \mathrm{kg}^{-1}$ de argila) e um Latossolo Vermelho ácrico ( $L V w)$ textura argilosa (440 $\mathrm{g} \mathrm{kg}^{-1}$ de argila), durante o periodo de reforma do canavial. O delineamento experimental foi em blocos casualizados com quatro cultivos e cinco blocos. Os cultivos foram: soja; soja/pousio/soja; soja/milheto/soja; $e$ soja/crotalária/soja. A amostragem de solo foi realizada em junho de 2011. Não foram verificadas diferenças significativas na quantidade de glomalina total, após a utilização das diferentes culturas. Maior comprimento de micélio externo total foi observado no solo onde houve os cultivos de soja / milheto / soja e soja/crotalária /soja. Foram observadas diferenças entre os solos avaliados para os atributos glomalina facilmente extraível, glomalina total e indice de estabilidade de agregados do solo, tendo o LVef apresentado características mais favoráveis que o LVw. Nenhuma das culturas utilizadas no periodo de reforma do canavial teve efeitos benéficos no índice de estabilidade de agregados nos dois Latossolos estudados.
\end{abstract}

Termos de indexação: glomalina, hifas, Latossolo Vermelho eutroférrico, Latossolo Vermelho ácrico.

\section{INTRODUCTION}

Conservative soil management systems have proved effective in preserving the activity of soil microorganisms. Crop rotations can alter microbial habitats via nutrient uptake by plants, differences in root depth between the cultivated species and the quality of plant residues left on the soil (Balota et al., 2004). Crop rotations and/or sequences facilitate mycorrhizal symbiosis and their favourable effect on plants; also, they foster the propagation of arbuscular mycorrhizal fungi (AMF) in the soil (Miranda \& Miranda, 1997).

Arbuscular mycorrhizal fungi, which are mutualistic symbionts living in association with the roots of most terrestrial plants, are essential for the soil-plant system because of their influence on soil fertility and plant nutrition (Smith \& Read, 2008). In fact, AMF increase soil aggregation and structural stability through the combined action of extraradical hyphae exploring soil to form an aggregate network and an insoluble protein called "glomalin" (Bedini et al., 2009), which has binding properties. According to Berbara et al. (2006), this hyphal function is very important because structured soil facilitates nutrient mobilization, water retention and root penetration, while reducing erosion. Also, aggregates provide a favourable and protected habitat for soil microorganisms and facilitate root oxygenation (Denef et al., 2001). In addition, the adhesive properties of glomalin facilitate binding of soil particles to form aggregates (Wright \& Upadhyaya, 1996; Purin, 2005).
Several studies have shown a significant relationship between the amount of glomalin present in soil and aggregate stability (Wright \& Upadhyaya, 1998). Thus, management systems in which soil tillage is avoided and the amount of organic matter left on the soil surface increased contribute to the improvement of some soil physical properties and the establishment of an optimal environment for microbial growth (particularly of mycorrhizal fungi, which are beneficial to plants and improve the soil structure by facilitating aggregate formation and stabilization). Therefore, a cropping system favouring AMF development will also facilitate sustainability.

Our working hypothesis was that the cultivation of some ground cover species improves the soil physical properties and development of arbuscular mycorrhizal fungi (AMF). The main purpose of this study was therefore to assess the effect of growing various crops during the sugarcane fallow period on production of glomalin and AMF propagules in two different Latosols, as well as their influence on soil aggregation.

\section{MATERIAL AND METHODS}

The experiment was conducted in two different areas in the municipality of Jaboticabal, São Paulo

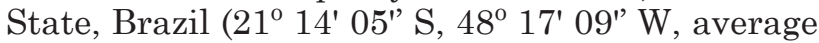
height $615 \mathrm{~m}$ asl). The soil in one area was an eutroferric Red Latosol $\left(\mathrm{RL}_{\mathrm{e}}\right)$ with high-clay texture $\left(\right.$ clay $=680 \mathrm{~g} \mathrm{~kg}^{-1}$, silt $=180 \mathrm{~g} \mathrm{~kg}^{-1}$, sand $=140 \mathrm{~g} \mathrm{~kg}^{-1}$ ) and that in the other an acric Red Latosol $\left(\mathrm{RL}_{2}\right)$, with 
clayey texture $\left(\right.$ clay $=440 \mathrm{~g} \mathrm{~kg}^{-1}$, silt $=120 \mathrm{~g} \mathrm{~kg}^{-1}$, sand $\left.=440 \mathrm{~g} \mathrm{~kg}^{-1}\right)$. The climate in both areas is Aw, according to Köppen's classification. The average temperature of the warmest and coldest month is, respectively, 22 and $18{ }^{\circ} \mathrm{C}$, and the average annual rainfall $1,424 \mathrm{~mm}$.

The experiment was arranged in a randomized block design, with four treatments (crops in the sugarcane fallow period) and five replications. The crops used in the fallow period (October 2008 to February 2010) were soybean/millet/soybean (SMS treatment 1), soybean/sunn hemp/soybean (SHS treatment 2) and soybean/fallow/soybean (SFS treatment 3). In these treatments SMS, SHS and SFS, two soybean (Glycine max) crops were grown (from October 2008 to February 2009 and October 2009 to February 2010). The period in-between (from March to September 2009), was used to plant millet (Pennisetum americanum) in SMS and sunn hemp (Crotalaria juncea) in SHS or for a fallow period (SFS). Treatment 4 consisted of soybean (S) from October 2009 to February 2010. A more detailed description of the crop installation and management was given by Fernandes et al. (2012).

The different crops in the fallow period were followed by mechanical planting of sugarcane in February 2010. Disturbed soil samples from the 0.00-0.10 m layer were collected for analysis with an auger at three different points per plot after the first sugarcane harvest in June 2011. The samples were used to determine easily extractable glomalin (EEG), total glomalin (TG), total external mycelium length (TEML), spore production (SP) and aggregate stability (water-stable aggregates-WSA). Additional disturbed samples collected with a mattock were used to determine the aggregate mean weight diameter (AMWD).

Easily extractable glomalin was obtained as described by Rillig et al. (2003) and quantified according to Bradford (1976). Total external mycelium was extracted according to Melloni \& Cardoso (1999) and mycelium length calculated by the simplified equation of Newman (1966). Spores were extracted by wet sieving as described by Gerdemann \& Nicholson (1963). Aggregate stability (WSA) and aggregate mean weight diameter (AMWD) were estimated according to Nimmo \& Perkins (2002); WSA was determined in 2.0-1.0 mm and AMWD in 6.3-4.0 $\mathrm{mm}$ diameter aggregates, using sieves of 4.0, 2.0, 1.0, $0.5,0.25$ and $0.125 \mathrm{~mm}$ mesh size.

Data were subjected to analysis of variance (ANOVA) in randomized blocks with five replications of each of the four treatments, followed by a combined analysis of the experiments, taking both soil types into consideration. Means were compared by Tukey's test at $\alpha<0.05$. The spore production values were log $(x+5)$ transformed. Correlations between soil properties (WSA, AMWD and SP) and the variables (EEG, TG and TEML) were assessed by Pearson's correlation coefficients.

\section{RESULTS AND DISCUSSION}

No significant differences between soil treatments were detected in easily extractable glomalin (EEG) or total glomalin (TG) in either soil $\left(\mathrm{RL}_{\mathrm{e}}\right.$ or $\left.\mathrm{RL}_{\mathrm{a}}\right)$ (Table 1$)$. These results indicate that the cover crop treatments in the fallow period of sugarcane (18 months) were probably insufficient to induce significant alterations in the glomalin content of the soils. It should be noted that the sugarcane preceding the treatments was a monoculture system, which may have affected the local AMF community. In this sense, Siqueira et al. (2007) found that millet monoculture caused changes in native AMF in soils in the USA. Also, the cultivation of a single plant species is known to diminish AMF diversity (Carrenho et al., 2010). For example, Oehl et al. (2003) found that maize monoculture reduced the spore density of two different soil AMF by more than $60 \%$. Consequently, the sugarcane monoculture preceding this study may have reduced the AMF community at the study site, resulting in reduced glomalin production in both soils.

The glomalin contents of this study are similar to those reported by Purin (2005) in an aluminic Humic Cambisol with 490-570 $\mathrm{g} \mathrm{kg}^{-1}$ clay under conventional and organic apple cultivation in Santa Catarina (Lages, Brazil). However, glomalin contents can vary over a wide range. Thus, Fokom et al. (2012) studied a field with peanut and maize intercropped with cassava and banana, and found an EEG and TG value of 6.51 and $8.45 \mathrm{mg} \mathrm{g}^{-1}$, respectively; in comparison, they found EEG $=10.56 \mathrm{mg} \mathrm{g}^{-1}$ and $\mathrm{TG}=15.67 \mathrm{mg} \mathrm{g}^{-1}$ in forest soils. Bird et al. (2002) reported low protein contents not exceeding $0.3-0.6 \mathrm{mg} \mathrm{g}^{-1}$ in soils containing 786-815, 125-146 and 60-78 $\mathrm{g} \mathrm{kg}^{-1}$ sand, silt and clay, respectively, under pasture in New Mexico, USA. Wright \& Upadhyaya (1996, 1998) reported glomalin fractions of acid soils in several USA regions of $1-15 \mathrm{mg} \mathrm{g}^{-1}$. In some soils (e.g., tropical soils in Hawaii about 4.1 million years old), the TG can exceed $100 \mathrm{mg} \mathrm{g}^{-1}$ (Rillig et al., 2001).

The high-clay soil $\left(\mathrm{RL}_{\mathrm{e}}\right)$ in this study had a higher glomalin content than the clayey soil $\left(\mathrm{RL}_{\mathrm{a}}\right)$, with $39 \%$ more EEG and $26 \%$ more TG in the former (Table 1). Although the most influential factors for glomalin production in soil have not been unequivocally identified, a combination of nutrient concentrations, climate, host type, and AMF diversity seemingly influences the deposition of glomalin in soil (Rillig et al., 2001). Also, glomalin contents can differ between soil types (Wu et al., 2012). The variability in this study may have been a result of the different textural classes of $R L_{e}$ and $R L_{a}$. Souza et al. (2011) examined the influence of various extractants and the sample storage temperature on the glomalin content determined in a Fluvic Neosol and a Luvisol containing 147 and $269 \mathrm{~g} \mathrm{~kg}^{-1}$ clay, respectively. They found that the Luvisol contained more glomalin and ascribed this result to the higher clay content of this soil. According 
to these authors, clay can have a protective action against microbial decomposers of glomalin. According to Wright \& Anderson (2000), some crop rotations, e.g., wheat/maize/millet in no-tillage boost glomalin production and increase soil aggregation more than other crop rotations that include sunflower. Therefore, the crops increasing soil stability and reducing erosion can often favour production and development of extraradical hyphae and glomalin fractions (Cardoso $\&$ Kuyper, 2006). Driver et al. (2005) found more than $80 \%$ of all AMF-produced glomalin contained in hyphal spores; according to these authors, salin contents may depend on the hyphal volume since glomalin is released into the soil when hyphae die or senesce.

For the data of total external mycelium length (TEML), there were significant interactions between the different crops in both soil types in the sugarcane fallow period (Table 2). Under S and SHS, TEML was greater in $\mathrm{RL}_{\mathrm{a}}$ than in $\mathrm{RL}_{\mathrm{e}}$. In $\mathrm{RL}_{\mathrm{e}}$, TEML was highest under SMS. This sequence and SHS also resulted in the greatest TEML in $\mathrm{RL}_{\mathrm{a}}$ (Table 2). These results suggest that grass and legume crops facilitate mycelial growth in soil. Also, extraradical mycelium development connects roots of various plants, thereby altering nutrient uptake dynamics (Silveira \& Freitas, 2007) and facilitating plant growth.

For mycorrhization, grasses are particularly qualified, due to the morphology of their root system, for having a higher volume of fine roots and an abundant, fast-growing root system (Cordeiro et al., 2005). The root system of soybean however has a high atmospheric $\mathrm{N}$ fixation capacity and residues of this legume are very easily degraded as a result of the lower $\mathrm{C} / \mathrm{N}$ ratio, which can contribute to the growth of native soil AMF. According to Rillig et al. (2002), the amount of mycelium in AMF accounts for more

Table 1. Easily extractable glomalin (EEG) and total glomalin (TG) in the 0.00-0.10 $\mathrm{m}$ soils layer after the first sugarcane harvest

\begin{tabular}{|c|c|c|c|c|c|c|c|}
\hline \multirow{2}{*}{ Crop (C) } & \multicolumn{2}{|c|}{$\mathrm{RL}_{\mathrm{e}}$} & \multicolumn{2}{|c|}{$\mathbf{R L}_{\mathrm{a}}$} & \multirow{2}{*}{ Soil (S) } & \multirow{2}{*}{ EEG } & \multirow{2}{*}{ TG } \\
\hline & EEG & TG & EEG & TG & & & \\
\hline \multirow[b]{2}{*}{$\mathrm{S}$} & - & $\mathrm{m}$ & 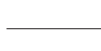 & & \multirow[b]{2}{*}{$\mathrm{RL}_{\mathrm{e}}$} & \multicolumn{2}{|c|}{$\mathrm{mg} \mathrm{g}^{-1}$ soil } \\
\hline & 1.19 & 4.13 & 0.88 & 3.45 & & $1.18 \mathrm{a}$ & $4.18 \mathrm{a}$ \\
\hline SFS & 1.12 & 4.15 & 0.86 & 3.35 & $\mathrm{RL}_{\mathrm{a}}$ & $0.85 \mathrm{~b}$ & $3.33 \mathrm{~b}$ \\
\hline SMS & 1.17 & 4.11 & 0.83 & 3.24 & F (soil) & $102.1^{* *}$ & $95.7^{* *}$ \\
\hline SHS & 1.24 & 4.34 & 0.82 & 3.25 & $\mathrm{~F}(\mathrm{C} \times \mathrm{S})$ & $0.99^{\text {ns }}$ & $1.03^{\text {ns }}$ \\
\hline F (crop) & $1.54^{\mathrm{ns}}$ & $0.96^{\mathrm{ns}}$ & $0.28^{\mathrm{ns}}$ & $0.56^{\mathrm{ns}}$ & & & \\
\hline CV (\%) & 7.63 & 5.96 & 13.8 & 8.85 & & & \\
\hline
\end{tabular}

S: soybean, SFS: soybean/fallow/soybean, SMS: soybean/millet/soybean, SHS: soybean/sunn hemp/soybean. Values followed by an identical letter in the same column were not significantly different as per Tukey's test at $\alpha=0.05$. ns not significant, ${ }^{* *}$ significant at the $\mathrm{p}=0.01$ level.

Table 2. Crop $\times$ soil interaction in total external mycelium length (TEML), in spore production (SP) and in aggregate mean weight diameter (AMWD, $\mathrm{mm}$ ) in the 0.00-0.10 $\mathrm{m}$ soils layer (eutroferric Red Latosol $\mathrm{RL}_{\mathrm{e}}$ and acric Red Latosol - $R \mathrm{~L}_{\mathrm{a}}$ ) after the first sugarcane harvest

\begin{tabular}{|c|c|c|c|c|c|c|}
\hline \multirow{2}{*}{ Crop (C) } & \multicolumn{2}{|c|}{ TEML } & \multicolumn{2}{|c|}{$\mathbf{S P}^{(1)}$} & \multicolumn{2}{|c|}{ AMWD } \\
\hline & $\mathrm{RL}_{\mathrm{e}}$ & $\mathbf{R L}_{\mathrm{a}}$ & $\mathrm{RL}_{\mathrm{e}}$ & $\mathrm{RL}_{\mathrm{a}}$ & $\mathbf{R L}_{\mathrm{e}}$ & $\mathbf{R L}_{\mathrm{a}}$ \\
\hline $\mathrm{S}$ & $0.86 \mathrm{Cb}$ & $1.29 \mathrm{Ba}$ & $0.60(0.74) \mathrm{Bb}$ & $8.00(1.11) \mathrm{ABa}$ & $2.69 \mathrm{Aa}$ & $2.98 \mathrm{Aa}$ \\
\hline SFS & $1.47 \mathrm{Ba}$ & $1.03 \mathrm{Bb}$ & $4.60(0.98) \mathrm{Aa}$ & $4.80(0.98) \mathrm{Ba}$ & $2.50 \mathrm{Aa}$ & $2.18 \mathrm{Ba}$ \\
\hline SMS & $2.36 \mathrm{Aa}$ & $2.11 \mathrm{Aa}$ & $0.80(0.76) \mathrm{Bb}$ & $9.20(1.15) \mathrm{Aa}$ & $2.45 \mathrm{Aa}$ & $2.56 \mathrm{ABa}$ \\
\hline SHS & $1.03 \mathrm{Cb}$ & $1.79 \mathrm{Aa}$ & $1.00(0.77) \mathrm{Bb}$ & $7.00(1.07) \mathrm{ABa}$ & $2.50 \mathrm{Aa}$ & $2.07 \mathrm{Bb}$ \\
\hline $\mathrm{F}$ (crops) $\mathrm{RL}_{\mathrm{e}}$ & \multicolumn{2}{|c|}{$37.1^{* *}$} & \multicolumn{2}{|c|}{$9.81^{* *}$} & \multicolumn{2}{|c|}{$0.67^{\mathrm{ns}}$} \\
\hline CV (\%) & \multicolumn{2}{|c|}{17.2} & \multicolumn{2}{|c|}{9.76} & \multicolumn{2}{|c|}{11.3} \\
\hline $\mathrm{F}$ (crops) $\mathrm{RL}_{\mathrm{a}}$ & \multicolumn{2}{|c|}{$23.1^{* *}$} & \multicolumn{2}{|c|}{$3.61^{*}$} & \multicolumn{2}{|c|}{$8.04^{* *}$} \\
\hline CV (\%) & \multicolumn{2}{|c|}{14.5} & \multicolumn{2}{|c|}{7.61} & \multicolumn{2}{|c|}{13.3} \\
\hline F (soil) & \multicolumn{2}{|c|}{$0.19^{\mathrm{ns}}$} & \multicolumn{2}{|c|}{$8.95^{\mathrm{ns}}$} & \multicolumn{2}{|c|}{$0.26^{\mathrm{ns}}$} \\
\hline $\mathrm{F}(\mathrm{C} \times \mathrm{S})$ & \multicolumn{2}{|c|}{$14.3^{* *}$} & \multicolumn{2}{|c|}{$12.0^{* *}$} & \multicolumn{2}{|c|}{$3.12^{*}$} \\
\hline
\end{tabular}

S: soybean, SFS: soybean/fallow/soybean, SMS: soybean/millet/soybean, SHS: soybean/sunn hemp/soybean, ${ }^{(1)}$ SP: number of spores per $50 \mathrm{~mL}$ soil. The data in brackets are means subjected to a log $(x+5)$ transformation Values followed by an identical capital letter in the same column or small letter in the same row were not significantly different as per Tukey's test at $\alpha=0.05$.

${ }^{n s}$ not significant, * and ** significant at the $\mathrm{p}=0.05$ and $\mathrm{p}=0.01$ level, respectively. 
than $50 \%$ of the total length of fungal hyphae, which is equivalent to $20-30 \%$ of all microbial mass in the soil. Therefore, AMF hyphae are effective mediators of soil aggregation and constitute a substantial portion of soil biomass (Miller et al., 1995). Judging from the absence of correlation between hyphal mass and soil aggregation found in this work, the hyphae did probably not act in stabilizing soil aggregates. This can be ascribed to the soil textural classes - fungal hyphae are more active in soils containing higher proportions of sand. Thus, Lutgen et al. (2003) previously reported a TEML value of $50 \mathrm{~m} \mathrm{~g}^{-1}$ for pasture soil containing $145 \mathrm{~g} \mathrm{~kg}^{-1}$ clay.

The interactions between crops in AMF spore production (SP) in both soil types were significant (Table 2). In $\mathrm{RL}_{\mathrm{e}}$ only $\mathrm{SP}$ was highest in SFS. Also, SP peaked in $\mathrm{RL}_{\mathrm{a}}$ under SMS and SHS.

There were no significant differences in aggregate stability (WSA) between crops in either soil (Table 3). Fernandes et al. (2012) previously found no differences in WSA in the acric Red Latosol $\left(\mathrm{RL}_{\mathrm{a}}\right)$ either after the sugarcane fallow period (i.e., after growth of the cover crops, and a few years before the present experiment was conducted).

The WSA data of this study suggest that soil tilling for sugarcane planting may have reduced aggregate stability in the soils. In fact, WSA was 20, 25, 22 and $30 \%$ lower with S, SFS, SMS, and SHS, respectively, in $\mathrm{RL}_{\mathrm{e}}$ than the values previously reported by Fernandes et al. (2012); and 25, 23, 20 and $18 \%$ lower, respectively, in $\mathrm{RL}_{\mathrm{a}}$. In $\mathrm{RL}_{\mathrm{e}}$, WSA was higher than in $\mathrm{RL}_{\mathrm{a}}$ (Table 3), as a result of the differences in textural classes between the two soils. In addition to climate and soil management practices, texture has a high influence on aggregate stability because the soil clay content affects aggregation via the expansion and dispersion of soil particles.

Madari et al. (2005) studied an eutroferric Red Latosol containing 726-800 $\mathrm{g} \mathrm{kg}^{-1}$ clay, which had been

Table 3. Aggregate stability (WSA) in the 0.00-0.10 m soil layer after the first sugarcane harvest

\begin{tabular}{|c|c|c|c|c|}
\hline \multirow{2}{*}{ Soil use (C) } & $\mathrm{RL}_{\mathrm{e}}$ & $\mathbf{R L}_{\mathrm{a}}$ & \multirow{2}{*}{ Soil (S) } & \multirow{2}{*}{ WSA } \\
\hline & \multicolumn{2}{|c|}{ WSA } & & \\
\hline & \multicolumn{2}{|c|}{$\%$} & & $\%$ \\
\hline $\mathrm{S}$ & 76.80 & 65.80 & $\mathrm{RL}_{\mathrm{e}}$ & $74.65 \mathrm{a}$ \\
\hline SFS & 74.20 & 62.80 & $\mathrm{RL}_{\mathrm{a}}$ & $64.10 \mathrm{~b}$ \\
\hline SMS & 76.00 & 63.20 & F (soil) & $71.85^{* *}$ \\
\hline SHS & 71.60 & 64.60 & $\mathrm{~F}(\mathrm{C} \times \mathrm{S})$ & $0.78^{\mathrm{ns}}$ \\
\hline F (crop) & $1.62^{\mathrm{ns}}$ & $0.40^{\mathrm{ns}}$ & & \\
\hline CV (\%) & 5.42 & 7.57 & & \\
\hline
\end{tabular}

S: soybean, SFS: soybean/fallow/soybean, SMS: soybean/millet/ soybean, SHS: soybean/sunn hemp/soybean. Values followed by an identical letter in the same column were not significantly different as per Tukey's test at $\alpha=0.05$. ${ }^{\mathrm{ns}}$ not significant, ** significant at the $\mathrm{p}=0.01$ level. under no tillage and conventional tillage, under crop rotation and succession for 12 years, and found no differences in soil aggregation. Garcia \& Rosolem (2010) examined a Latosol under no-tillage crop rotation with brachiaria in autumn-winter, sorghum and sorghum/brachiaria in spring with millet, cover crop (Sorghum bicolor $\times$ S. sudanense), sunn hemp and fallow, and soil aggregation was also found to be unaffected by the particular treatment used in the first year of assessment. However, the WSA after the third crop rotation year revealed favourable effects of the previous plant species on the top $(0-10 \mathrm{~cm})$ soil layer. According to these authors, the absence of soil turnover and the plant residues left on the soil surface, in addition to continuous root growth, are essential for preserving and improving soil aggregation. According to Garcia \& Rosolem (2010), aggregation can be boosted by root exploration, since during plant growth, soil particles are drawn closer to each other over time.

Significant differences were stated in aggregate mean weight diameter (AMWD) between crops and soils (Table 2). In $\mathrm{RL}_{\mathrm{e}}$, AMWD was similar for all crops; by contrast, in $\mathrm{RL}_{\mathrm{a}}$, AMWD was higher in the treatment $\mathrm{S}$ than in SFS and SHS, but similar to SMS. The AMWD was highest with SHS in $\mathrm{RL}_{\mathrm{e}}$. Garcia \& Rosolem (2010) also found that cover crops (Sorghum bicolor and S. sudanense, sunn hemp and millet) increased AMWD over fallow from the first year. They suggested that an increase in dry matter production by aerial part and root growth in grasses facilitates soil aggregation.

In this work, Pearson's correlations between soil aggregation and aggregate mean weight diameter with total external mycelium length and glomalin were not significant in either soil (Table 4). This result contradicts most previous findings in this respect. Caravaca et al. (2006) examined aggregate stability after inoculation with mycorrhizal fungi and found that fungi increase soil aggregation substantially. They associated fungal development to an increased aggregate stability by effect of fungal hyphae improving the soil structure. In fact, mycorrhizal fungi are essential for a successful replanting of degraded areas and soil structure preservation with a view to avoiding erosion (Caravaca et al., 2006). Thus, several studies involving inoculation of various AMF species have revealed beneficial effects on soil aggregation. For example, Bedini et al. (2009) examined changes in soil aggregation caused by inoculation of mycorrhizal fungi of the species Glomus and found AMWD to be correlated with total hyphal length as well as with glomalin. Some field studies also revealed positive correlations between these properties (Fokom et al., 2012; Wu et al., 2012). In a long-term study of no-tillage and conventional planting with and without liming, Albuquerque et al. (2005) found correlations between aggregate stability and the amount of fungal mycelia. 
Table 4. Pearson's correlation coefficients between variables - aggregate stability (WSA), aggregate mean weight diameter (AMWD) and spore production (SP) - and easily extractable glomalin (EEG), total glomalin (TG) and total external mycelium length (TEML) in the 0.00-0.10 m layer after the first sugarcane harvest

\begin{tabular}{|c|c|c|c|c|c|c|}
\hline \multirow{2}{*}{ Variable } & \multicolumn{3}{|c|}{$\mathrm{RL}_{\mathrm{e}}$} & \multicolumn{3}{|c|}{$\mathrm{RL}_{\mathrm{a}}$} \\
\hline & EEG & TG & TEML & EEG & TG & TEML \\
\hline WSA & $-0.244^{\mathrm{ns}}$ & $0.105^{\mathrm{ns}}$ & $0.306^{\mathrm{ns}}$ & $-0.122^{\mathrm{ns}}$ & $-0.082^{\mathrm{ns}}$ & $0.014^{\mathrm{ns}}$ \\
\hline AMWD & $-0.037^{\mathrm{ns}}$ & $-0.265^{\mathrm{ns}}$ & $-0.033^{\mathrm{ns}}$ & $-0.170^{\mathrm{ns}}$ & $-0.244^{\mathrm{ns}}$ & $-0.141^{\mathrm{ns}}$ \\
\hline SP & $-0.194^{\mathrm{ns}}$ & $0.003^{\mathrm{ns}}$ & $0.018^{\mathrm{ns}}$ & $-0.065^{\mathrm{ns}}$ & $-0.098^{\mathrm{ns}}$ & $0.440^{\mathrm{ns}}$ \\
\hline
\end{tabular}

${ }^{\mathrm{ns}}$ not significant.

Based on our results, neither AMF hyphal growth nor glomalin contribute to aggregate stability in either Latosol $\left(\mathrm{RL}_{\mathrm{e}}\right.$ or $\left.\mathrm{RL}_{\mathrm{a}}\right)$. In addition to the crops used during the sugarcane fallow period, the fact that the study area was previously under a sugarcane monoculture for years may have affected AMF propagation at the local level. According to Purin \& Klauberg Filho (2010), efficient glomalin production by mycelia in soil requires not only deposition and incorporation of plant residues, but also uptake and relocation of nutrients to the host plants via the fungi. Only under these conditions can resources be efficiently used by mycelia to produce the protein. Agricultural operations used to plant the crops and sugarcane in the study area must have resulted in increased soil turnover and may have disrupted the AMF hyphal network involving soil aggregates, thereby reducing glomalin production and potentially affecting local propagation of the fungi and, ultimately, diminishing their contribution to aggregate stabilization. According to Entry et al. (2002), tillage of the soil surface exposes some fungal structures acting as propagules (viz, spores, hyphae and colonized roots), affecting them directly by sunlight, high temperatures and moisture changes.

The fact that this study involved field work and the short cultivation period of the crops resulted in low positive correlations between soil aggregation and the presence of mycorrhizal fungi. Alternative factors may thus have played a role in stabilizing soil aggregates. It is noteworthy that soil aggregation is known to be affected by other soil microorganisms such as different fungi and bacteria as well (Tisdall $\&$ Oades, 1979). In addition to substantially increasing soil quality, and hence agricultural production, AMF favour the uptake of low-mobility soil nutrients by plants. It should be noted that most studies reporting correlations between aggregate stability indices and mycorrhizal fungi were conducted with AMF inoculation in several-year-old no-tillage systems, in greenhouses or in the field. Although no correlation between these properties was found here, the results of this study are important in view of the lack of information about the role of glomalin and hyphae in stabilizing soil aggregates (especially in a production environment as that of sugarcane plantations). Further research is therefore required on the main factors governing aggregation in these soils with a view to facilitating the development of AMF communities, given their fundamental role in soil aggregation and plant growth.

\section{CONCLUSIONS}

1. None of the crops tested in the sugarcane fallow period had a favourable effect on aggregate stability in either soil $\left(\mathrm{RL}_{\mathrm{e}}\right.$ or $\left.\mathrm{RL}_{\mathrm{a}}\right)$.

2. The treatments soybean (S), soybean/millet/ soybean (SMS) and soybean/sunn hemp/soybean (SHS) increased the number of AMF spores in the acric Red Latosol $\left(\mathrm{RL}_{\mathrm{a}}\right)$.

3. Using millet or sunn hemp between two soybean crops resulted in increased development of total external mycelium length in the acric Red Latosol $\left(\mathrm{RL}_{\mathrm{a}}\right)$, and so did use of the sequence soybean/millet/ soybean (SMS) in the eutroferric Red Latosol $\left(\mathrm{RL}_{\mathrm{e}}\right)$.

4. None of the four soil treatments (S, SFS, SMS, and SHS) altered the glomalin content of $\mathrm{RL}_{e}$ or $\mathrm{RL}_{\mathrm{a}}$.

\section{LITERATURE CITED}

ALBUQUERQUE, J.A.; MAFRA, A.L.; FONTOURA, S.M.V.; BAYER, C. \& PASSOS, J.F.M. Avaliação de sistemas de preparo e calagem em um Latossolo Bruno alumínico. R. Bras. Ci. Solo, 29:963-975, 2005.

BALOTA, E.L.; KANASHIRO, M.; COLOZZI FILHO, A.; ANDRADE, D.S. \& DICK, R.P. Soil enzyme activities under long-term tillage a crop rotation systems in subtropical agro-ecosystems. Braz. J. Microbiol., 35:300306, 2004.

BEDINI, S.; PELlEGRINO, E.; AVIO, L.; PELLEGRINI, S.; BAZZOFFI, P.; ARGESE, E. \& GIOVANNETTI, M. Changes in soil aggregation and glomalin-related soil protein content as affected by arbuscular mycorrhizal fungal species Glomus mosseae and Glomus intraradices. Soil Biol. Biochem., 41:1491-1496, 2009. 
BERBARA, R.L.L.; SOUZA, F.A. \& FONSECA, H.M.A.C. Fungos micorrízicos arbusculares: Muito além da nutrição. In: FERNANDES, M.S., ed. Nutrição mineral de plantas. Viçosa, MG, Sociedade Brasileira de Ciência do Solo, 2006. p.54-79.

BIRD, S.B.; HERRICK, J.E.; WANDER, M.M. \& WRIGHT, S.F. Spatial heterogeneity of aggregate stability and soil carbon in semi-arid rangeland. Environ. Pollut., 116:445-455, 2002.

BRADFORD, M.M. A rapid and sensitive method for the quantitation of microgram quantities of protein utilizing the principle of protein-dye binding. Anal. Biochem., 72:248-254, 1976.

CARAVACA, F.; ALGUACIL, M.M.; AZCÓN, R. \& ROLDÁN, A. Formation of stable aggregate in rhizosphere soil of Juniperus oxycedrus: Effect of AM fungi and organic amendments. Appl. Soil Ecol., 33:30-38, 2006.

CARDOSO, I.M. \& KUYPER, T.W. Mycorrhizas and tropical soil fertility. Agric. Ecosyst. Environ., 116:72-84, 2006.

CARRENHO, R.; GOMES-DA-COSTA, S.M.; BALOTA, E.L. \& COLOZZI FILHO, A. Fungos micorrízicos arbusculares em agrossistemas brasileiros. In: SIQUEIRA, J.O.; SOUZA, F.A.; CARDOSO, E.J.B.N. \& TSAI, S.M., eds. Micorrizas: 30 anos de pesquisa no Brasil. Lavras, Universidade Federal de Lavras, 2010. p.215-249.

CORDEIRO, M.A.S.; CARNEIRO, M.A.C.; PAULINO, H.B. \& SAGGIN-JUNIOR, O.J. Colonização e densidade de esporos de fungos micorrízicos em dois solos do cerrado sob diferentes sistemas de manejo. Pesq. Agropec. Trop., 35:147-153, 2005.

DENEF, K.; SIX, J.; BOSSUYT, H.; FREY, S.D.; ELLIOT, E.T.; MERCKX, R. \& PAUSTIAN, K. Influence of dry-wet cycles on the interrelationship between aggregate, particulate organic matter, and microbial community dynamics. Soil Biol. Biochem., 33:1599-1611, 2001.

DRIVER, J.D.; HOLBEN, W.E. \& RILLIG, M.C. Characterization of glomalin as hyphal wall component of arbuscular mycorrhizal fungi. Soil Biol. Biochem., 37:101-106, 2005.

ENTRY, J.A.; RYGIEWICS, P.T.; WATRUD, L.S. \& DONNELLY, P.K. Influence of adverse soil conditions on the formation and function of arbuscular mycorrhizas. Adv. Environ. Res., 7:123-138, 2002.

FERNANDES, C.; CORÁ, J.E. \& MARCELO, A.V. Soil uses in the sugarcane fallow period to improve chemical and physical properties of two Latosols (Oxisols). R. Bras. Ci. Solo, 36:283-294, 2012.

FOKOM, R.; ADAMOU, S.; TEUGWA, M.C.; BEGOUDE BOYOGUENO, A.D.; NANA, W.L.; NGONKEU, M.E.L.; TCHAMENI, N.S.; NWAGA, D.; TSALA NDZOMO, G. \& AMVAM ZOLLO, P.H. Glomalin related soil protein, carbon, nitrogen and soil aggregate stability as affected by land use variation in the humid forest zone of South Cameroon. Soil Till. Res., 120:69-75, 2012.

GARCIA, R.A. \& ROSOLEM, C.A. Agregados em um Latossolo sob sistema plantio direto e rotação de culturas. Pesq. Agropec. Bras., 45:1489-1498, 2010.
GERDEMANN, J.W. \& NICHOLSON, T.H. Spores of mycorrhizal Endogene species extracted from soil by wet sieving and decanting. Trans. Braz. Mycol. Soc., 46:235244, 1963.

LUTGEN, E.R.; MUIR-CLAIRMONT, D.; GRAHAM, J. \& RILLIG, M. Seasonality of arbuscular mycorrhizal hyphae and glomalin in a western Montana grassland. Plant Soil, 257:71-83, 2003.

MADARI, B.; MACHADO, P.L.O.A.; TORRES, E.; ANDRADE, A.G. \& VALENCIA, L.I.O. No tillage and crop rotation effects on soil aggregation and organic carbon in a Rhodic Ferralsol from Southern Brazil. Soil Till. Res., 80:185$200,2005$.

MELLONI, R. \& CARDOSO, E.J.B.N. Quantificação de micélio extrarradicular de fungos micorrízicos arbusculares em plantas cítricas e endófitos. I. Método empregado. R. Bras. Ci. Solo, 23:53-58, 1999.

MILLER, R.M.; REINHARDT, D.R. \& JASTROW, J. External hyphal production of vesicular-arbuscular mycorrhizal fungi in pasture and talgrass prairie communities. Oecologia, 103:17-23, 1995.

MIRANDA, J.C.C. \& MIRANDA, L.N. Micorriza arbuscular. In: VARGAS, M.A. \& HUNGRIA, M., eds. Biologia dos cerrados. Brasília, Embrapa/CPAC, 1997. p.69-123.

NEWMAN, E.I. A method for estimating the total length of root in a sample. J. Appl. Ecol., 3:139-145, 1966.

NIMMO, J.R. \& PERKINS, K.S. Aggregate stability and size distribution. In: DANE, J.H. \& TOPP, G.C., eds. Methods of soil analysis. Madison, Soil Science Society of America, 2002. Part 4. p.317-328 (SSSA Book Series, 5)

OEHL, F.; SIEVERDING, E.; INEICHEN, K.; MADER, P.; BOLLER, T. \& WIEMKEN, A. Impact of land use intensity on the species diversity of arbuscular mycorrhizal fungi in agroecossystems of Central Europe. Appl. Environ. Microbiol., 69:2816-2824, 2003.

PURIN, S. Fungos micorrízicos arbusculares: atividade, diversidade e aspectos funcionais em sistemas de produção de maçãs. Lages, Universidade do Estado de Santa Catarina, 2005. 182p. (Dissertação de Mestrado)

PURIN, S. \& KLAUBERG FILHO, O. Glomalina: Nova abordagem para entendermos a biologia dos fungos micorrízicos arbusculares. In: SIQUEIRA, J.O.; SOUZA, F.A.; CARDOSO, E.J.B.N. \& TSAI, S.M., eds. Micorrizas: 30 anos de pesquisa no Brasil. Lavras, Universidade Federal de Lavras, 2010. p.215-249.

RILLIG, M.C.; RAMSEY, P.W.; MORRIS, S. \& PAUL, E.A. Glomalin, an arbuscular-mycorrhizal soil protein, responds to land-use change. Plant Soil, 253:293-299, 2003.

RILLIG, M.C.; WRIGHT, S.F. \& EVINER, V.T. The role of arbuscular mycorrhizal fungi and glomalin in soil aggregation: Comparing effects of five plant species. Plant Soil, 238:325-333, 2002.

RILLIG, M.C.; WRIGHT, S.F.; NICHOLS, K.A.; SCHMIDT, W.F. \& TORN, M.S. Large contribution of arbuscular mycorrhizal fungi to soil carbon pools in tropical forest soils. Plant Soil, 233:167-177, 2001. 
SILVEIRA, A.D.P. \& FREITAS, S.S. Microbiota do solo e qualidade ambiental. Campinas, Instituto Agronômico Campinas, 2007. 312p.

SIQUEIRA, J.O.; SOARES, C.R.F.S.; SANTOS, J.G.; SCHNEIDER, J. \& CARNEIRO, M.A.C. Micorrizas e degradação do solo: Caracterização, efeitos e ação recuperadora. In: CERETTA, C.S.; SILVA, L.S. \& REICHERT, J.M., eds. Tópicos em ciência do solo. Viçosa, MG, Sociedade Brasileira de Ciência do Solo, 2007. v.5, p.219-306.

SMITH, S.E. \& READ, D.J. Mycorrhizal symbiosis. London, Academic Press, 2008. 787p.

SOUZA, C.S.; MENEZES, R.S.C.; SAMPAIO, E.V.S.B. \& LIMA, F.S. Influências da temperatura de armazenamento e de extratores na determinação de glomalina em solos paraibanos. R. Ci. Agron., 42:837-841, 2011.

TISDALL, J.M. \& OADES, J.M. Stabilization of soil aggregates by the root system of ryegrass. Aust. J. Soil Res., 17:429441, 1979.
WRIGHT, S.F. \& ANDERSON, R.L. Aggregate stability and glomalin in alternative crop rotations for the central Great Plains. Biol. Fertil. Soils, 31:249-253, 2000 .

WRIGHT, S.F. \& UPADHYAYA, A. A survey of soils for aggregate stability and glomalin, a glycoprotein produced by hyphae of arbuscular mycorrhizal fungi. Plant Soil, 198:97-107, 1998.

WRIGHT, S.F. \& UPADHYAYA, A. Extraction of an abundant and unusual protein from soil and comparison with hyphal protein of arbuscular mycorrhizal fungi. Soil Sci., 161:575-586, 1996.

WU, Q.S.; ELE, X.H.; ZOU, Y.N.; ELE, K.P.; SUN, Y.H. \& CAO, M.Q. Spatial distribution of glomalin-related soil protein and its relationships with root mycorrhization, soil aggregates, carbohydrates, activity of protease and â-glucosidase in the rhizosphere of Citrus unshiu. Soil Biol. Biochem., 45:181-183, 2012. 